\title{
The quality of nata de coco from sawarna and mapanget coconut varieties to the time of storing coconut water
}

\author{
${ }^{1,{ }^{*} \text { Santosa, B., }}{ }^{2}$ Wignyanto, W., ${ }^{2}$ Hidayat, N. and ${ }^{2}$ Sucipto, S. \\ ${ }^{I}$ Department of Agro Industrial Technology, Tribhuwana Tunggadewi University, Malang, Indonesia \\ ${ }^{2}$ Department of Agro Industrial Technology, Brawijaya University, Malang, Indonesia
}

\begin{abstract}
Article history:
Received: 9 November 2019

Received in revised form: 3

December 2019

Accepted: 3 December 2019

Available Online: 23

December 2019
\end{abstract}

\section{Keywords:}

Nata de coco,

Coconut,

Storage time

DOI:

https://doi.org/10.26656/fr.2017.4(4).372

\begin{abstract}
This study was aimed to find out the type of coconut water and its storage time in order to get the best of nata de coco quality. The design of experiments conducted in this study nested random design 2 factors. The main factor coconut varieties consisting of two levels: palm fruit varieties sawarna and the coconut fruit varieties mapanget, the storage time of coconut water is nested in palm varieties which consists of 5 levels i.e. $0,6,12,18$ and $24 \mathrm{hrs}$. Each treatment was repeated 3 times so that the total of all 30 samples. The results showed that the nata de coco best coconut water obtained from fresh. However, it demonstrated that coconut water stored for $6 \mathrm{hrs}$ of varieties of sawarna, the quality of nata de coco generated no difference from nata de coco coconut water varieties of fresh mapanget ( $0 \mathrm{hrs}$ of storage) and reducing sugar in coconut water varieties sawarna is an important factor as the carbon source for Acetobacter xylinum. Thus, in order to get nata de coco with the best quality, coconut water of sawarna varieties which is still fresh or has been stored for $6 \mathrm{hrs}$ can be used.
\end{abstract}

\section{Introduction}

Coconut water as a product of coconut fruits processed can be used as raw materials for making nata (Hamad et al., 2011; Lestari et al., 2014). Nata raw material is also easily obtained, available at any time and there are in each area. Indonesia has the largest land oil plants in the world with a total area of 3.82 million hectares with a production of 15.9 billion grains of coconuts per year which are mostly used to meet domestic needs (Rukmana and Yudirachman, 2016). This suggests that the use of coconuts by Indonesian society is very high, which means coconut water waste generated is also high.

The utilization of coconut water as raw material for making nata de coco so far is still derived from a mixture of various coconut varieties. Nutrient content, especially sugar in coconuts, is different for each variety. Varieties that are easily obtained, especially in Indonesia, are coconut varieties, especially coconut varieties in Sawarna (DSA) and coconut in Mapanget (DMT) (Rukmana and Yudirachman, 2016). This potential is one of the supporters of the continued supply of nata de coco raw materials.

DMT and DSA varieties have the same $\mathrm{pH}$ of 5.5 and total DMT solids are $5.95 \%$ higher than DSA of
$5.69 \%$. DSA reduction sugar by $3.95 \%$ is greater than DMT by $3.11 \%$, whereas DMT potassium content is greater, ie $280 \mathrm{mg} / 100 \mathrm{~g}$ compared to DSA of 249.7 $\mathrm{mg} / 100$ g. DSA varieties with DMT have the same sodium content of $51 \mathrm{mg} / 100 \mathrm{~g}$, while the vitamin C content of DMT is greater $(2.46 \mathrm{mg} / 100 \mathrm{~g})$ when compared to DSA $(2.24 \%)$. Calcium content of DMT is greater, which is $40 \mathrm{mg} / 100 \mathrm{~g}$ when compared to DSA of $35.3 \mathrm{mg} / 100 \mathrm{~mL}$ (Runtuwu et al., 2011)

Nata de coco fiber in the form of cellulose at $2.5 \%$ (Hidayat et al., 2006; Gea et al., 2010; Ma et al., 2012). In addition to the high fiber content, this product has other advantages that the manufacturing process is easy and does not require a long time. This differs from the fruits and vegetables that require a long time to be consumed as a source of fiber.

Workmanship for using coconut water from a mixture of different varieties of coconuts while the use of coconut water from one variety to the manufacture of this product has not been done. The content of nutrients, especially sugar in the coconut fruit is different for each variety. Sugar in the making of this beverage products plays a very important because cellulose fiber is formed during the fermentation of sugars derived from (Jung et al., 2010; Castro et al., 2011; Anas et al., 2012; Sunagawa et al., 2013). 
Coconut water use in the manufacture of these products is generally nata maker cannot use fresh coconut water directly due to various factors such as the distance between the source of raw materials to the place of production, transportation constraints and limitations of the production site. Factors that cause coconut water should be kept by the manufacturer before it is processed further nata.

During storage, fermented coconut water will be carried out by the natural microbes that may cause deterioration in chemical nutrients, especially in sugar because sugar is the best carbon source for microbial growth (Naufalin and Wibowo, 2004; Zeng et al., 2011; Alwi et al., 2015). Decreased levels of this sugar will affect the quality of the resulting cellulose fibers. Research on the use of coconut water that has undergone a process of storage as a raw material of nata de coco has not been conducted so far. This study was aimed to investigate the type of coconut water and its storage time to obtain the best quality of nata de coco.

\section{Materials and methods}

\subsection{Raw material}

The materials used in this study were the coconut water from coconut varieties sawarna (DSA) and varieties mapanget (DSM) enough old, obtained from Dampit village of Malang. Old age criteria from coconut husk are dark brown color, flesh thickness of $1.5 \mathrm{~cm}$ and coconut milk can be taken. Figure 1 shows the epidermis color and thickness of coconut flesh between Sawarna (DSA) and Mapanget (DMT) varieties. Acetobacter xylinum obtained from the Microbiology Laboratory of the UB, sucrose, glucose, extracts of yeast, peptone bacto, glacial acetic acid, $\mathrm{Na}_{2} \mathrm{HPO}_{4}, \mathrm{MgSO}_{4} 7 \mathrm{H}_{2} \mathrm{O}$, gelatin, $\mathrm{H}_{2} \mathrm{SO}_{4}, \mathrm{NaOH}$, Aquadest, $\mathrm{K}_{2} \mathrm{SO}_{4}$ and $\mathrm{CaCO}_{3}$.

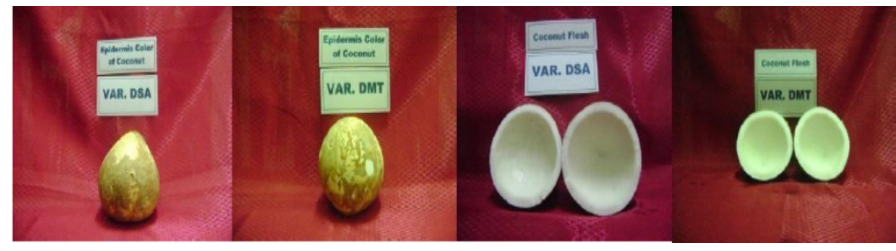

Figure 1. Color the epidermis as well as the thickness of the coconut meat DSA and DMT

\subsection{Breeding Acetobacter xylinum in starter}

Starter namely strains $A$. xylinum cultured in the medium. Making the starter is done by growing a pure strain into the coconut water from coconut varieties sawarna and the coconut fruit varieties mapanget were enriched using nutrients in the form of sucrose and ammonium sulfate and $\mathrm{pH}$ of the media was made into a 4 by adding glacial acetic acid. The number of $A$. xylinum that will be inoculated into the fermentation medium uniform i.e. $2 \times 10^{7}$ cells $/ \mathrm{mL}$. To reach the cell number is calculated directly using hemocytometer (Oliveira et al., 2015; Sulistyani et al., 2016)

\subsection{Nata de coco production}

Good coconut water from coconut varieties sawarna and varieties mapanget is boiled at $100^{\circ} \mathrm{C}$ for 15 mins. Further thereto are added nutrients in the form of sucrose $2 \%$ and $0.06 \%$ ammonium sulfate number then boiled again. After the media poured into fermentation tanks and closed using parchment paper and further straining cloth is tied using a rubber band. Media were allowed to cool for $12 \mathrm{hrs}$ after it was made into a media $\mathrm{pH} 4$ by adding glacial acetic acid into $20 \mathrm{~mL}$ of media. Starter inoculation A. xylinum into the media so that it ferments further incubated for 14 days.

\subsection{Experimental design}

The experimental design used in this study is a randomized design nested 2 factors. The first factor coconut varieties consisting of two levels, namely $\mathrm{Vr} 1=$ varieties sawarna (DSA), $\mathrm{Vr} 2=$ varieties mapanget (DMT). While the second factor old coconut water storage which consist of 5 level including $\mathrm{P} 1=0 \mathrm{hr}, \mathrm{P} 2=$ $6 \mathrm{hrs}, \mathrm{P} 3=12 \mathrm{hrs}=18 \mathrm{hrs} \mathrm{P} 4, \mathrm{P} 5=24 \mathrm{hrs}$. The second factor is nested on the first factor, each treatment was repeated 3 times, so we obtained 30 samples.

\subsection{The observation of nata de coco}

Observation of $\mathrm{pH}$ in the nata de coco fermentation media was carried out every day for 14 days (Brooks et al., 2013), cell development of $A$. xylinum methods Total Plate Count/ TPC (AOAC, 2002) and the thickness of nata (Gayathry, 2015). Whereas, the weight parameters (Gayathry, 2015) and the total fiber content of nata de coco (McCleary, 2014) were observed on day 14 after harvesting.

\subsection{Data analysis}

Data obtained during the study were analyzed using Analysis of Variance (ANOVA). If there is a real difference then a further test by using Honestly Significant Difference (HSD) at $\alpha=5 \%$ is conducted (Hanafi, 2012; Kumalaningsih, 2012).

\section{Results and discussion}

\section{$3.1 \mathrm{pH}$}

Different varieties of coconut and coconut water storage time significantly affect the condition of 1 growth A. xylinum in the process of nata pellicle formation. The stages of the formation of nata takes place during the fermentation process. During the fermentation process, 

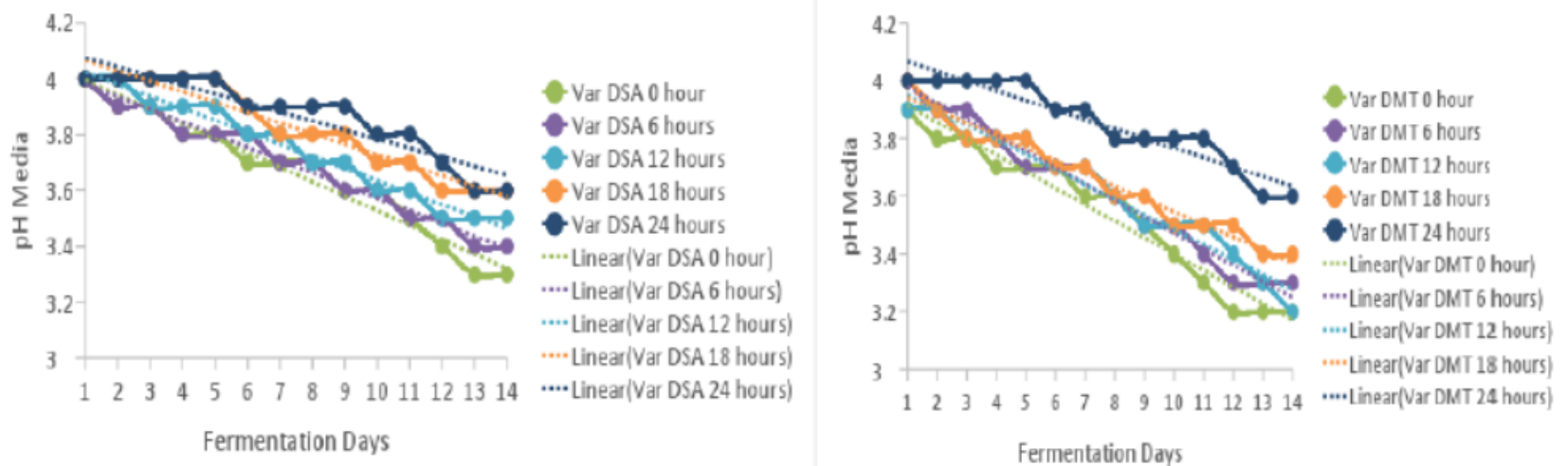

Figure 2. Graphic of growing media of $\mathrm{pH}$ A. xylinum during fermentation (14 days) on DSA and DMT on different time coconut water storage

the $\mathrm{pH}$ of the media as one of the conditions for the growth of $A$. xylinum had decreased since the first days of fermentation. It can be seen in Figure 2.

Varieties of media $\mathrm{pH}$ DSA and DMT are significantly different. DMT varieties $\mathrm{pH}$ is more acidic than varieties DSA though, during fermentation, a decrease in $\mathrm{pH}$ between the two varieties is likely to be similar. Different coconut water storage time significantly gave an effect on the condition of the media $\mathrm{pH}$. The $\mathrm{pH}$ of fresh coconut water varieties DMT $(0 \mathrm{hrs}$ of storage) gives the average $\mathrm{pH}$ more acidic than other treatments do. The longer the storage time of coconut water, growing media $\mathrm{pH}$ rise although still under acidic conditions. Fresh coconut water ( 0 hrs of storage) had a $\mathrm{pH}$ ranging from 3.20 to 3.33 while coconut water that had been stored for more than $6 \mathrm{hrs}$ of storage $(6,12,18$ and $24 \mathrm{hrs}$ of storage) had a higher $\mathrm{pH}$ than the $\mathrm{pH}$ of fresh coconut water. This shows that the longer the storage time of coconut water, the more increasing the $\mathrm{pH}$ of the media. This typical $\mathrm{pH}$ conditions may affect the growth of $A$. xylinum as the $\mathrm{pH}$ of the media is one of the requirements that must be met in order that $A$. xylinum can grow well in the process of nata pellicle formation.

During the 14-day fermentation, the $\mathrm{pH}$ of the growing medium of A. xylinum decreased gradually, increasingly acidic. This condition caused the activity of the A. xylinum increased so nata pellicle formation process could run well. These conditions will produce nata de coco with good quality. Lestari et al. (2014) stated that $A$. xylinum can grow well in a medium with some condition that sufficient nutrients mainly containing a carbon source, a source of nitrogen, minerals, vitamins and media $\mathrm{pH}$ is acidic $\mathrm{pH}$. In the process of nata pellicle formation, $\mathrm{pH}$ is necessary for the growth of A. xylinum which is ranging between 3-4 (Castro et al., 2011; Gea et al., 2011). During fermentation, the $\mathrm{pH}$ of the growing medium of coconut varieties that vary with a different time storage, media
$\mathrm{pH}$ coconut water as a medium for growing $A$. xylinum is still under acidic conditions (ranging in Figure 2) so that the condition is still supporting activity of $A$. xylinum in the process of formation of pellicle nata.

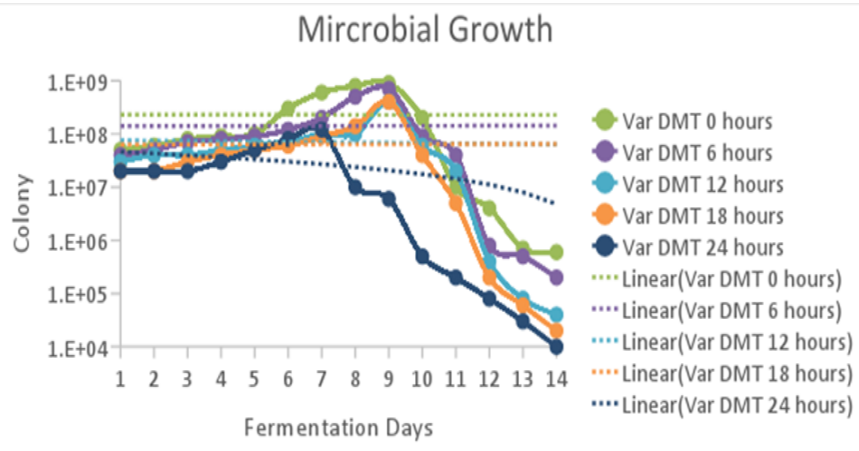

Figure 3. Graphic of growth of A. xylinum during fermentation (14 days) in coconut water media variety mapanget (DMT) with different coconut water storage time

\subsection{Growth of Acetobacter xylinum}

Graphic of the growth of $A$. xylinum for nata fermentation pellicle formation can be seen in Figure 3 .

The graphic above shows that the different coconut varieties did not affect the growth of $A$. xylinum significantly during fermentation. Different coconut water storage time significantly gives effect on the growth of A. xylinum. The average growth of A. xylinum is the highest on the media which are still fresh coconut water ( $0 \mathrm{hrs}$ of storage) in both the DSA and DMT varieties. The growth $A$. xylinum continued to increase from the first day until the day of fermentation to-9 fermentation. The highlight of the growth A. xylinum reached an average of the highest value on day 9 of the fermentation. Today the $10^{\text {th }}$ until the $14^{\text {th }}$ day of growth suffered a sharp decline. On the $14^{\text {th }}$ day, nata de coco was harvested. This bacterium is an obligate aerobic bacterium that works to synthesize cellulose from sugar in the womb of a material (Alwi et al., 2015). The growth A. xylinum can run well on a medium with the requirements of sufficient nutrients, especially glucose (Jung et al., 2010). 
Table 1.Variety effect of coconut and coconut water storage time on the quality of nata de coco

\begin{tabular}{lcccc}
\hline \multicolumn{1}{c}{ Treatment } & Nata thickness $(\mathrm{cm})$ & Nata Weight $(\mathrm{g})$ & Nata crude fiber $(\%)$ & Sugar reduction (\%) \\
\hline DSA 0 hrs & $1.87 \pm 0.03$ & $246.67 \pm 5.77$ & $2.01 \pm 0.05$ & $3.25 \pm 0.01$ \\
DSA 6 hrs & $1.62 \pm 0.03$ & $210.00 \pm 10.00$ & $1.91 \pm 0.05$ & $3,14 \pm 0.01$ \\
DSA12 hrs & $1.43 \pm 0.06$ & $173.33 \pm 5.77$ & $1.58 \pm 0.02$ & $3.03 \pm 0.01$ \\
DSA 18 hrs & $1.25 \pm 0.05$ & $146.67 \pm 5.77$ & $1.40 \pm 0.03$ & $2.85 \pm 0.01$ \\
DSA 24 hrs & $1.11 \pm 0.01$ & $123.33 \pm 5.77$ & $1.31 \pm 0.03$ & $2.68 \pm 0.01$ \\
DMT 0 hrs & $1.48 \pm 0.02$ & $206.67 \pm 11.55$ & $1.81 \pm 0.03$ & $3.01 \pm 0.01$ \\
DMT 6 hrs & $1.32 \pm 0.02$ & $163.33 \pm 5.77$ & $1.56 \pm 0.04$ & $2.99 \pm 0.01$ \\
DMT 12 hrs & $1.21 \pm 0.01$ & $138.33 \pm 2.89$ & $1.40 \pm 0.05$ & $2.97 \pm 0.01$ \\
DMT18 hrs & $1.17 \pm 0.02$ & $113.33 \pm 5.77$ & $1.30 \pm 0.07$ & $2.49 \pm 0.01$ \\
DMT 24-hour & $0.94 \pm 0.04$ & $95.00 \pm 5.00$ & $1.18 \pm 0.02$ & $2.02 \pm 0.01$ \\
\hline
\end{tabular}

A. xylinum will continue to grow over the nutrients as long as the support growth is still available. It is visible on the first day until the $9^{\text {th }}$ day of fermentation. The graphic of A. xylinum growth continued to increase since glucose (sugar) was much provided. On the 10th day of the fermentation, the growth of $A$. xylinum decline. This is possible because the nutrients necessary for the growth of $A$. xylinum has been reduced so that its growth is also slowing. Such conditions will certainly affect the quality of nata de coco generated. Wijayanti et al. (2016) suggested the formation stages nata pellicle layer in the form of cellulose hydrolysis process begins with the sucrose produces glucose and fructose using enzymes sucrase and invertase. When sucrose is in the growing medium has reduced the activity of $A$. xylinum also be decreased and nata produced is also unlikely to grow significantly when compared to the beginning of fermentation. That's why the common nata were harvested on the $14^{\text {th }}$ day of fermentation.

\subsection{Nata de coco quality}

The quality observation parameter of nata de coco includes thickness, weight and crude fiber of nata. This can be seen in Table 1. Table 1 shows the varieties and coconut water storage time affects the quality of nata de coco generated. DSA varieties are better than DMT in improving the quality of nata de coco. This is because the reducing sugar content of DSA variety coconut water is higher than DMT (Runtunuwu et al., 2011). Coconut water containing sugar reduction in high levels has great potential as a medium for fermentation because it contains sugar which can serve as a fermentable sugar as well as a carbon source for the microbes (Yanuar and Sutrisno, 2015). In making nata de coco, sugar plays an important role as a source of carbon that can be changed by $A$. xylinum cellulose layer nata (Bhanthumnavin et al., 2016; Sainz et al., 2017).

Coconut water storage time also significantly affects the quality of nata de coco generated on all parameters nata observations in thickness, weight and crude fiber of nata. The use of fresh coconut water ( $0 \mathrm{hrs}$ of storage) nata de coco provides the best quality when compared with coconut water that has been stored for $6,12,18$ or $24 \mathrm{hrs}$. Nata de coco produced from coconut water stored in various storage periods with an interval of $6 \mathrm{hrs}$ produces nata de coco with different qualities. The longer it is stored coconut water, nata de coco quality resulting in a decline in all parameters of observation in Figure 4.

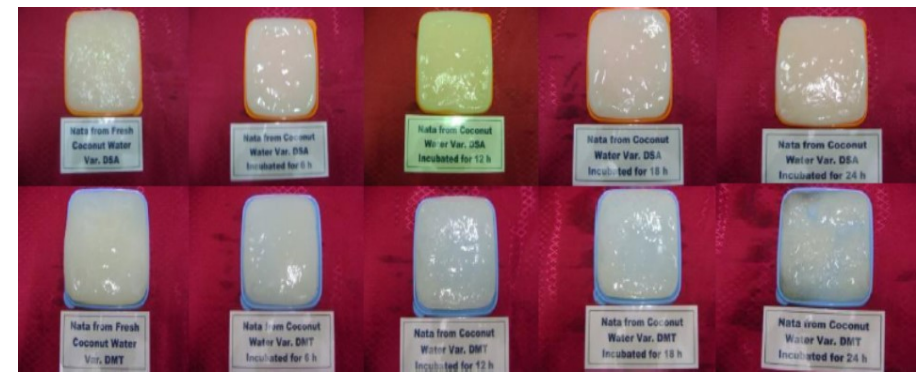

Figure 4. Nata de coco from coconut water varieties DSA and DMT

The quality of nata de coco of fresh DSA variety (0 hrs of storage) is better than fresh DMT variety with the thickness of $1.87 \mathrm{~cm}$, the weight of $246.67 \mathrm{~g}$, the crude fiber of $2.01 \%$, sugar reduction of $3.25 \%$ compared to storage treatment for 6.12 and $24 \mathrm{hrs}$. DSA varieties with a storage time of coconut water for $6 \mathrm{hrs}$, the quality of nata de coco is still better than fresh DMT varieties with a thickness of $1.62 \mathrm{~cm}$, a weight of $210 \mathrm{~g}$, the crude fiber of $1.91 \%$ and a sugar reduction of $3.14 \%$. DSA varieties with 12 hrs long storage have better nata de coco quality compared to DMT, namely with a thickness of $1.43 \mathrm{~cm}$, a weight of $173.33 \mathrm{~g}$, the crude fiber of $1.58 \%$ and a sugar reduction of $3.034 \%$. The quality of nata de coco in 18 hrs storage time, DSA variety was better than DMT variety with nata thickness difference of $0.08 \mathrm{~cm}$, nata weight of $33.34 \mathrm{~g}$, the crude fiber of $0.10 \%$ and sugar reduction of $0.36 \%$. The quality of nata de coco in $24 \mathrm{hrs}$ storage time, DSA variety is better than DMT variety with nata thickness difference of $0.16 \mathrm{~cm}$, nata weight of $28.33 \mathrm{~g}$, crude fiber of $0.13 \%$ and sugar reduction of $0.56 \%$. This difference is one of them caused by the reducing sugar content of DSA which is higher than 
DMT.

The stages of nata formation take place during the fermentation process. Stages of nata formation involve microorganisms, namely A. xylinum. This bacterium is an obligate aerobic bacterium that works by synthesizing cellulose from sugar in the content of an ingredient (Alwi et al., 2011). A. xylinum can grow well in a medium with several conditions, namely adequate nutrition, especially containing carbon (C), a source of nitrogen $(\mathrm{N})$, minerals, vitamins, and media $\mathrm{pH}$ is an acidic $\mathrm{pH}$ (Lestari et al., 2014). The carbon element can be obtained from natural sugars contained in a material such as glucose, fructose and sucrose, so that the bacteria can work and can form a layer of nata (Pratiwi and Aryawati, 2012; Lempang, 2013). Wijayanti et al. (2016) stated the stages of the formation of a layer of nata pellicle in the form of cellulose begin with the hydrolysis of sucrose or starch which produces glucose and fructose using the enzyme sucrase and invertase enzymes.

Glucose or fructose that is formed is then converted into cellulose by A. xylinum. The formation of cellulose from glucose begins with the process of phosphorylation in glucose to glucose-6-phosphate which is catalyzed by the enzyme glucokinase. Furthermore, undergo an isomerization process which is catalyzed by the enzyme phosphoglucomutase to glucose-1-phosphate. After that, the formation of UDP-glucose is aided by the enzyme UDPG firophosphorylase and the formation of cellulose strings outside the cell with the help of the enzyme cellulose synthase (Anas et al., 2012; Sunagawa et al., 2013). Sugar plays an important role in making nata de coco, because as a carbon source that can be converted by $A$. xylinum into a layer of cellulose nata (Bhanthumnavin et al., 2016; Sainz et al., 2017).

Most makers of nata de coco cannot immediately take advantage of fresh coconut water to be used as nata because of distance factor between the source of coconut water to the plant that is quite far, limited transportation or means of production, so sometimes coconut water is stored for several hrs before they were made into nata de coco, from the research that has been conducted, it is indicated that the best nata de coco produced was from fresh coconut water. However, it demonstrated that coconut water stored for $6 \mathrm{hrs}$ of varieties of DSA, the quality of nata de coco generated no different with nata de coco coconut water varieties of fresh DMT (0 hrs of storage). This means that reducing the sugar content of coconut water varieties stored DSA for $6 \mathrm{hrs}$ is still insufficient to meet the needs of a carbon source of $A$. xylinum the formation cellulose nata layer. Reducing sugar in coconut water varieties DSA is an important factor as the carbon source for A. xylinum. Although it kept for $6 \mathrm{hrs}$, the reduction of sugar levels is still sufficient for the microbial source of carbon for forming a layer of cellulose. Thus, to get nata de coco with the best quality can use coconut water varieties DSA is still fresh or has been stored for 6 hrs.

\section{Conclusion}

Good quality nata de coco is obtained from DSA variety coconut water with coconut water storage time for $6 \mathrm{hrs}$ with a thickness of $1.62 \mathrm{~cm}$, the weight of 210 $\mathrm{g}$, the crude fiber of $1.91 \%$ and sugar reduction of $3.14 \%$. The quality of nata de coco produced from DSA variety coconut water with a long storage time of coconut water for $6 \mathrm{hrs}$ is better than the quality of nata de coco produced from fresh DMT variety (0 hrs of storage) coconut water which in this study was used as a control treatment.

\section{Conflict of Interest}

The authors declare no conflict of interest.

\section{Acknowledgments}

The author would like to thank all those who have helped in the conduct of the research and all parties who have helped in this research, especially to Brawijaya University and Tribhuwana Tunggadewi University.

\section{References}

Alwi, M., Lindhemuthianingrum, A. and Umrah, U. (2015). Growing media formulation Acetobacter xylinum of liquid waste materials tempe and coconut water for production nata de soya coco. Biocelebes, 5(2), 126-132

Anas, A.K., Atika, S. and Firman, N. (2012). Effect of Variations Massa Bulbs Canna (Cannaedulis) on Preparation and Characterization of Plastic-Based Biodegradable Sustainable Canna Bulbs. Yogyakarta, Indonesia: Yogyakarta University.

AOAC.(2002).Official Methods of Analysis of The Association of Official Analytical Chemists. Washington DC, USA: Association of Official Analytical Chemists.

Bhanthumnavin, W., Wanichapichart, P., Taweepreeda, W., Sirijarukula, S. and Paosawatyanyong, B. (2016). Surface modification of bacterial cellulose membrane by oxygen plasma treatment. Surface and Coatings Technology, 306(Part A), 272-278. https:// doi.org/10.1016/j.surfcoat.2016.06.035

Brooks, L.M., Kuhlman, B.J., McKesson, D.W. and McCloskey, L. (2013). Poor interoperability of the Adams-Harbertson method for analysis of 
anthocyanins: comparison with AOAC $\mathrm{pH}$ differential method. Journal of AOAC International, 96(1), 86-90. https://doi.org/10.5740/jaoacint.12-216

Castro, C., Zuluaga, R., Putaux, J.L., Caro, G., Mondragon, I. and Gañán, P. (2011). Structural characterization of bacterial cellulose produced by Gluconacetobacter swingsii sp. from Colombian agroindustrial wastes. Carbohydrate Polymers, 84 (1), $\quad$ 96-102. j.carbpol.2010.10.072

Gayathry, G. (2015). Production of nata de coco a natural dietary fiber products from mature coconut water using Gluconacetobacter xylinum. International Journal of Food Fermentation Technology, 5(2), 231-235. https:// doi.org/10.5958/2277-9396.2016.00006.4

Gea, S., Bilotti, E., Reynolds, C.T., Soykeabkeaw, N. and Peijs, T. (2010). Bacterial cellulose-poly (vinyl alcohol) nanocomposites prepared by an in-situ process. Materials Letters, 64(8), 901-904. https:// doi.org/10.1016/j.matlet.2010.01.042

Gea, S., Reynolds, C.T., Roohpour, N., Wirjosentono, B., Soykeabkaew, N., Bilotti, E. and Peijs, T. (2011). Investigation into the structural, morphological, mechanical and thermal behaviour of bacterial cellulose after a two-step purification process. Bioresource Technology, 102(19), 9105-9110. https://doi.org/10.1016/j.biortech.2011.04.077

Hamad, A., Andriyani, N.A., Wibisono, H. and Sutopo, H. (2011). Pengaruh penambahan sumber karbon terhadap kondisi fisi knata de coco. Techno, 12(2), 74-77.

Hanafi, K.A. (2012). Design of Experiments (Theory and Applications). Jakarta, Indonesia: Rajawali Press.

Hidayat, N., Masdiana C., Padaga. and Kumalaningsih, S. (2006). Industrial microbiology. Yogyakarta: Andi.

Jung, H.I., Jeong, J.H., Lee, O.M., Park, G.T., Kim, K.K., Park, H.C. and Son, H.J. (2010). Influence of glycerol on production and structural-physical properties of cellulose from Acetobacter sp. V6 cultured in shake flasks. Bioresource Technology, 101(10), 3602-3608. https://doi.org/10.1016/ j.biortech.2009.12.111

Kumalaningsih, S. (2012). Research methodology (peel completed how to achieve objectives). Malang, Indonesia: UB Press.

Lempang, M. (2013). Produksi nata fruit cans dari nira nipah. Jurnal Penelitian Hasil Hutan, 31(2), 110119. [In Bahasa Indonesia]. https://doi.org/10.20886/ jphh.2013.31.2.110-119

Lestari, P., Elfrida, N., Suryani, A. and Suryadi, Y.
(2014). Study on the production of bacterial cellulose from Acetobacter xylinum using agrowaste. Jordan Journal of Biological Sciences, 7(1), 75-80. https://doi.org/10.12816/0008218

Ma, T., Ji, K., Wang, W., Wang, J., Li, Z., Ran, H., Ran, H., Liu, B. and Li, G. (2012). Cellulose synthesized by Enterobacter sp. FY-07 under aerobic and anaerobic conditions. Bioresource Technology, 126, 18-23. https://doi.org/10.1016/j.biortech.2012.09.040

McCleary, B.V. (2014). Modification to AOAC official methods 2009.01 and 2011.25 to allow for minor overestimation of low molecular weight soluble dietary fiber in samples containing starch. Journal of AOAC International, 97(3), 896-901. https:// doi.org/10.5740/jaoacint.13-406

Naufalin, R. and Wibowo, C. (2004).Pemanfaatan hasil samping pengolahan tepung tapioca untuk pembuatan nata de cassava: kajian penambahan sukrosa dan ekstrak ke cambah. Jurnal Teknologi Industri Pangan, 15(2), 153-158.

Oliveira, P.M., Brosnan, B., Furey, A., Coffey, A., Zannini, E. and Arendt, E.K. (2015). Lactic acid bacteria bioprotection applied to the malting process. Part I: Strain characterization and identification of antifungal compounds. Food Control, 51, 433-443. https://doi.org/10.1016/j.foodcont.2014.07.004

Pratiwi, A. and Aryawati, R. (2012). Pengaruh waktu fermentasi terhadap sifat fisik dan kimia pada pembuatan minuman kombucha dari rumput laut Sargasssum sp. Maspari Journal: Marine Science Research, 4(1), 131-136.

Rukmana, R. and Yudirachman, H. (2016). Fortunately pleated of coconut cultivation plants multi benefit. Yogyakarta, Indonesia: Lyli Publisher.

Runtunuwu, S.D., Assa, J., Rawung, D. and Kumolontang, W. (2011). Chemical ingredients meat and water fruit coconut composite ten elders. Bulletin Palma, 12(1), 57-65.

Sainz, F., Mas, A. and Torija, M.J. (2017). Effect of ammonium and amino acids on the growth of selected strains of Gluconobacter and Acetobacter. International Journal of Food Microbiology, 242, 45 -52 .

https://doi.org/10.1016/

j.ijfoodmicro.2016.11.006

Sulistyani, H., Fujita, M., Miyakawa, H. and Nakazawa, F. (2016). Effect of roselle calyx extract on in vitro viability and biofilm formation ability of oral pathogenic bacteria. Asian Pacific Journal of Tropical Medicine, 9(2), 119-124. https:// doi.org/10.1016/j.apjtm.2016.01.020

Sunagawa, N., Fujiwara, T., Yoda, T., Kawano, S., Satoh, Y., Yao, M., Tajima, K. and Dairi, T. (2013). 
Cellulose complementing factor (Ccp) is a new member of the cellulose synthase complex (terminal complex) in Acetobacter xylinum. Journal of Bioscience and Bioengineering, 115(6), 607-612. https://doi.org/10.1016/j.jbiosc.2012.12.021

Wijayanti, E., Hastuti, U.S. and Rohman, F. (2016). The effect of sugar sorts on thick and weight of nata from pommelo citrus (Citrus maxima (burn. f.) nambangan cultivar. Research Report, 2, 326-332.

Yanuar, S.E. and Sutrisno, A. (2015). Minuman probiotik dari air kelapa muda dengan starter bakteri asam laktat lactobacillus casei. Jurnal Pangan dan Industri, 3, 909-917.

Zeng, X., Small, D.P. and Wan, W. (2011). Statistical optimization of culture conditions for bacterial cellulose production by Acetobacter xylinum BPR 2001 from maple syrup. Carbohydrate Polymers, 85 (3), 506-513. https://doi.org/10.1016/ j.carbpol.2011.02.034 